\title{
MAKNA RAGAM HIAS MOTIF NAGO BESAUNG \\ PADA KAIN SONGKET PALEMBANG
}

\author{
Oleh: \\ Decky Kunian \\ (Dosen FKIP Program Studi Pendidikan Sendratasik Universitas PGRI Palembang)
}

\begin{abstract}
Abstrak
Penelitian yang berjudul "Makna Ragam Hias Motif Nago Besaung Pada Kain Songket Palembang" ini, dimaksudkan untuk melihat makna simbolik motif nago besaung dalam pernikahan masyarakat Palembang. pendekatan yang digunakan adalah pendekatan simbol. Dalam pendekatan simbol peneliti memandang motif nago besaung sebagai sebuah teks. Untuk memahami teks tentang motif nago besaung, peneliti menggunakan konsep pemahaman masyarakat Palembang untuk mendukung hasil penelitiannya. Hasil penelitian menunjukkan bahwa simbolisasi dari motif nago besaung merupakan unsur kepercayaan dari masyarakat Palembang yang di dalamnya mengadung pemahaman dan kepercayaan akan kekuatan naga karena mengganggap naga sebagai lambang yang memiliki nilai-nilai magis, spiritual, kebaikan, perlindungan, ke makmuran, dan kebijaksanaan. Konsep tersebut dituangkan dalam visual songket yang mengharapkan akan memiliki kesamaan sifat dari unsur naga itu sendiri untuk pemakainya.
\end{abstract}

Kata kunci: Makna Simbolik, motif Nago Besaung, Kain Songket.

\section{A.PENDAHULUAN}

Bagian selatan Sumatera yang terkenal dengan kain songketnya yaitu Palembang. Sementara orang menyebut Palembang ini mengingatkan nama tempat di mana pernah ada Kerajaan Sriwijaya yang memerintah sekitar abad VIII sampai XI. Kerajaan laut yang menguasai perdagangan di sekitar Selat Malaka, bahkan pengaruhnya sampai Cina, Champa dan Siam. Menurut sejarah dan kebudayaan Palembang tampak bahwa kejayaan masa lampau tercermin melalui pakaian upacara dan pakaian adat, rumah adat, bentuk ukir-ukiran kayu, logam emas, perak dan sebagainya. Emas yang berlimpah ruah di masa kejayaan raja-raja pada waktu dahulu, tercermin dari penggunaan emas dalam tenunan kain songket dan arti emas dalam bentuk rumah adat limas (Kartiwa, 1989: 33). 
Ada pendapat yang menghubungkan bahwa benang emas yang terbuat dari logam murni yang berasal dari Palembang diimpor ke Cina dan kembali ke Palembang dalam bentuk benang emas yang dipakai untuk menghias pakaian mereka. Songket di Palembang dibedakan menjadi dua macam, yaitu songket lepus dan songket tawur atau songket berbatur. Songket lepus adalah songket yang ragam hiasnya dengan penggunaaan benang emas yang penuh. Sedangkan songket tawur atau songket berbatur adalah songket dengan desain benang emas yang tersebar atau berserak pada permukaan tenun songket. Perbedaan ini penting, di mana songket yang melambangkan kebesaran dan keagungan adat Palembang sangat menentukan martabat dan golongan yang memakainya (Alam, 1995: 17).

Dulu songket merupakan barang yang mewah, semua tidak terlepas dari bahan dasar dari pada songket itu sendiri, yaitu berbahan emas murni. Walaupun pada saat dulu songket telah dibedakan dengan adanya kandungan emas yang penuh (lepus) menutupi kain songket dan benang emas yang diletakkan secara berserakan (tawur) dimaksudkan untuk memberikan perbedaan strata sosial bagi masyarakat Palembang. Songket jenis lepus tentunya akan lebih berharga dibandingkan dengan songket jenis tawur, akan tetapi perkembangan selanjutnya benang emas dapat digantikan oleh benang sintetis berwarna emas, dimaksudkan untuk selain faktor ekonomis, agar semua masyarakat khususnya masyarakat Palembang dapat merasakan dan menikmati songket itu sendiri yang tentunya tanpa mengurangi nilai-nilai yang terkandung didalamnya.

Secara umum songket adalah kain yang ditenun dengan menggunakan benang emas atau perak dengan menggunakan teknik menyungkit, yaitu menyisipkan benang emas atau perak tersebut di bawah silangan benang lungsi (benang yang memanjang) dan benang pakan (benang yang melintang). Terdapat beberapa jenis songket misalnya songket bungo pacik, songke bungo berante, songket pulir, songket nago besaung, dan lain sebagainya. Di samping benang emas dan benang perak, ada yang menggunakan benang sulam, benang katun berwarna, ada yang menggunakan jenis-jenis benang sintesis dan lain sebagainya (Kartiwa, 1989:3).

Songket adalah kain hasil tenunan yang diberi ragam hias dengan cara menambahkan benang pakan dengan benang emas, perak atau benang berwarna lainnya 
pada waktu menenun (Kartiwa, 1989:5). Buku ragam hias songket Minangkabau dituliskan bahwa kain songket ialah kain katun yang diberi ragam hias dengan cara menambahkan benang pakan (horizontal waktu menenun) dengan benang emas, perak atau benang berwarna lainnya waktu menenun. Bila dilihat cara penambahan benang pakan dengan benang emas, perak dan benang berwarna lainnya ini, seperti menyungkit atau menenun (Nusyirwan, 1982: 9).

Sejak jaman dahulu hingga sekarang bahwa motif dan ragam hias pada kain songket Palembang diwariskan secara turun temurun. Dalam hal ini bahwa motif atau ragam hias yang diterapkan pada kain songket Palembang sebagian besar bermotif tumbuhan terutama yang berbentuk stilasi bunga-bungaan, di samping itu juga terdapat komposisi motif lain seperti, geometris, dekoratif dan binatang.

Masyarakat Palembang beranggapan bahwa tumbuhan merupakan lambang dari kehidupan dan manusia hidup dari tumbuh-tumbuhan tersebut. Unsur tumbuh-tumbuhan yang sering diterapkan ialah pucuk rebung, daon sireh dan lain sebagainya. Motif bungabungaan tersebut dapat dikaitkan dengan kebudayaan Palembang seperti daun simbar (pakis menjangan) dimana tanaman tersebut selalu tumbuh di tempat yang tinggi dan selalu menempel pada tanaman lain, tetapi tidak mengganggu tanaman yang ditempelinya. Maka mereka menyimpulkan bahwa filosofis tersebut melambangkan martabat masyarakat Palembang itu tinggi nilainya namun tidak merugikan lingkungan (Kartiwa, 1989: 35).

Motif binatang yang terdapat dalam kain songket Palembang sangat minim sekali, tetapi ada salah satu motif yaitu nago besaung yang mempunyai nilai filosofis tinggi dikarenakan erat kaitannya dengan raja (dewasa ini pengantin yang dianggap raja). Motif nago besaung merupakan penggambaran dari bentuk naga yang dalam penerapanya motif ini terlihat menggambarkan bentuk naga yang saling berhadapan, yang seolah-olah digambarkan dalam keadaan bertarung satu sama lain, sehingga motif nago besaung juga dikenal dengan nama motif nago betarung sedangkan penamaan nago besaung berakar dari struktur satu kesatuan dari motif naga yang membentuk lingkaran yang diyakini mengandung makna sehingga juga dikenal dengan nama motif nago besaung. Motif pendukung pada tenun songket nago besaung ini adalah motif bungo melati yang 
diletakkan pada bagian badan kain yang disusun penuh sedangkan motif bungo mawar sebagai isian pada motif pokok.

Walaupun naga tidak dijumpai dalam kehidupan nyata, namun makhluk naga seolah hadir dalam kepercayaan masyarakat Palembang (mitos). Perlu dijelaskan di sini bahwa menurut sifatnya motif naga tergolong dalam ornamen stilasi. Naga tergolong dalam ornamen binatang atau makhluk imajinatif, Ornamen binatang untuk menyusun atau pembentukanya dapat dilakukan dengan cara meniru, menggayakan, mendistorsikan, atau mendeformasikan keseluruhan dan/atau sebagian organ tubuhnya (Guntur, 2004: 5-45). Penjelasan tersebut dapat digunakan sebagai acuan bahwa berbagai bentuk naga pada songket tentunya dijumpai dalam bentuk yang merupakan hasil menggayakan atau mendistorsikan dari sebagian atau seluruh badan naga.

Perlu dipahami bahwa banyaknya motif dalam kain songket Palembang yang biasa digunakan dalam acara tertentu seperti pernikahan, khitanan, ataupun cukuran bayi, akan tetapi ada salah satu motif yang biasa digunakan khusus dalam pernikahan yaitu motif nago besaung.

Kehadirannya erat sekali dalam acara pernikahan yang semua berakar dari keyakinan masyarakat Palembang memandang motif nago besaung memiliki makna simbolik sehingga digunakan sebagai busana pelengkap dalam prosesi pernikahannya.

Tentunya semua dapat dipahami dari latar belakang budaya Palembang yang jika melihat kebelakang adanya percampuran etnik dan budaya Cina (akulturasi), sehingga perkembangannyapun berlanjut pada konsepsi pola pikir masyarakat Palembang yang percaya akan makna simbolik motif nago besaung yang bersumber dari motif pokoknya yaitu naga.

Jika membandingkan keberadaan naga yang tidak terlepas dalam kebudayaan Palembang, semua tampak pada banyaknya ornamen naga yang menghiasi kota Palembang yang diyakini bukan hanya bernilai estetis tetapi juga memiliki makna simbolis, 
seperti pada pembatas jalan, perkarangan, pagar rumah, perahu, dan pada songket itu sendiri.

Paparan di atas tidak mengherankan adanya hubungan khusus antara motif nago besaung yang di visualkan kedalam kain songket karna diyakini memiliki makna khusus. Merujuk pada konsep tersebutlah sehingga motif nago besaung digunakan dalam acara pernikahan di kota Palembang yang diyakini memiliki unsur sarat makna, makna yang dapat menjadi pedoman dalam mengarungi kehidupan.

Pemaparan singkat di atas, memberikan ruang bagi peneliti untuk menggali secara mendetail dan mendalam mengenai makna simbolik motif nago besaung pada kain songket Palembang beserta elemen-elemen pendukungnya.

\section{B.METODE}

Penelitian ini merupakan penelitian kualitatif yang tujuannya adalah ingin mengetahui bentuk dan makna motif nago besaung pada songket Palembang, sehingga untuk mendata motif pokok beserta unsur pembentukkanya maka metode yang dapat digunakan adalah metode penelitian kualitatif deskriptif. Dimana metode-metode kualitatif menjurus pada pemahaman masyarakat setempat secara personal dan memandang mereka sebagaimana mereka sendiri menggunakan dunianya. Untuk dapat memperoleh data seperti yang sesuai dalam penelitian ini, maka perlu digunakan suatu metode pengumpulan data yang tepat yaitu; pertama studi pustaka dilakukan dengan mengumpulkan sumber pustaka yang berhubungan dengan masalah penelitian yang dikumpulkan dengan cara membaca lalu mencatat yang dianggap penting yang berhubungan dengan masalah penelitian, kedua dokumen tertulis dan arsip merupakan sumber data yang penting, terutama bila sasaran kajian pada latar belakang atau berbagai peristiwa yang terjadi dimasa lampau yang berkaitan dengan kondisi atau peristiwa masa kini yang sedang diteliti, ketiga Metode observasi merupakan salah satu metode yang dapat digunakan untuk keperluan suatu identifikasi. Hal tersebut karena cara kerja observasi menyadarkan pada pengamatan dan pencatatan. Observasi dilakukan secara langsung, artiya observasi cenderung dilakukan dengan cara mengamati secara langsung 
pada subyek maupun objek yang diteliti dan keempat wawancara kepada nara sumber yang kompeten.

\section{C.HASIL DAN PEMBAHASAN}

\section{A. Jenis Ragam Hias Songket Palembang}

Ragam hias songket Palembang secara visual dapat dibedakan menjadi beberapa macam. Ada ragam hias alami yang terdiri dari unsur-unsur alam dan ragam hias non alami yang merupakan hasil kreativitas pencipta, baik yang bentuknya mendekati unsur alam maupun kadang pula lepas dari unsur alam. pada ragam hias songket Palembang sejalan dengan pendapat (Soegeng Toekio, 1983/1984: 136) yang membedakan ragam hias menjadi empat yaitu; ragam hias geometris, tumbuh-tumbuhan, makhluk hidup dan dekoratif. Adapun jenis-jenis ragam hias dapat dipilah sebagai berikut:

1) Ragam hias geometris

Ragam hias geometris tergolong paling tua usianya. Ide dasar penciptaan ragam hias geometris tidak bertitik tolak pada obyek nyata maupun benda alam. Bentuknya sangat sederhana, lebih banyak mengungkapkan unsur-unsur yang beraturan. Bila diamati dari segi estetisnya maka komposisi dalam ragam hias geometris berdasarkan berwujud garis lurus atau lengkung yang menggambarkan (segitiga, segi empat, lingkaran dan segi banyak). Umumnya ragam hias geometris pada songket diterapkan sebagai hiasan pinggir kain songket yang lebih dikenal dengan nama pucuk rebung.

2) Ragam hias tumbuh-tumbuhan

Ragam hias kelompok ini menggunakan bentuk-bentuk flora atau tumbuhtumbuhan sebagai sumber gubahan dalam menciptakan pola hias. Untuk menciptakan ragam hias tumbuhan tidak seluruhnya dituangkan dalam bentuk yang serupa dengan aslinya, namun telah distilir atau disederhanakan sedemikian rupa sehingga bentuk ini memperoleh kesan baru. Perwujudan dalam obyek gubahan adalah dari tumbuhtumbuhan seperti daun, bunga, buah dan ranting.

Penggunaan ragam hias ini merupakan sumber gagasan utama yang banyak menghiasi tenun songket. Pada songket palembang terdapat berbagai jenis-jenis 
tumbuhan yang telah distilir sedemikian rupa, mulai dari bentuk bunga, daun dan kuncup. Ragam hias tumbuhan memegang peranan sebagai motif pokok atau pengisi.

Maka tidaklah heran jika banyaknya penerapan ragam hias terutama bungabungaan, tanpa disadari penerapan konsep ini telah masuk dalam pola pemikiran masyarakat Palembang yang lebih menyukai motif tumbuhan. Adapun motif bunga yang dimaksud adalah, bungo mawar, bungo melati, bungo tanjung, bungo manggis, bungo cino, bungo pacik dan lainya.

Setiap lembaran kain songket selalu menerapkan motif bunga melati, bunga mawar atau bunga tanjung karena dalam filosofi budaya Palembang motif tersebut mempunyai makna tertentu. Bunga melati melambangkan kesucian dan sopan santun, bunga mawar dilambangkan sebagai penawar malapetaka, dan bunga tanjung melambangkan ucapan selamat datang atau melambangkan sikap ramah tamah (Syamsir Alam, 1995: 20).

\section{3) Ragam hias makhluk hidup}

Ragam hias makhluk hidup ini, seperti manusia, binatang bahkan makhluk gaib menjadi unsur inspirasi penciptaan ragam hias. Dari bentuk visualnya yang realis seperti pada pahatan relief candi, hingga bentuknya yang dekoratif pada perbendaharaan seni hias Indonesia.

Seperti halnya pada ragam hias songket Palembang yang mengadopsi motif binatang yang telah distilisir dari bentuk aslinya, seperti motif nago betarung yang diambil dari unsur kebudayaan Cina.

Tidak begitu banyak ragam hias binatang yang diterapka pada tenun songket Palembang, karena dipengaruhi oleh kepercayaan masyarakat Palembang yang mayoritas memeluk agama Islam. Dimana ajaran Islam melarang menggambarkan bentuk-bentuk makhluk hidup, sehigga penggambarannya distilisir sedemikian mungkin dari bentuk aslinya. 


\section{4) Ragam hias dekoratif}

Pada kenyataannya ragam hias songket Palembang tidak hanya dari jeis satu motif, tetapi menggunakan variasi bermacam-macam ragam hias. Misalnya kombinasi dari ragam hias bunga dan binatang. Artinya semua motif dipergunakan secara bersama dalam satu bidang tenun.

Perkembangan teknologi dan akulturasi sangat berdampak pada ragam hias songket, khususnya songket Palembang. Corak ragam hias songket dengan bentuk bunga yang mengilhami dari kekayaan alam dan seni budaya daerah, juga mendapat pengaruh dari ragam hias daerah penghasil tenun songket lainnya. Hal ini mengakibatkan songket palembang baik dalam motif tertentu memiliki kesamaan dengan daerah lain. Hanya saja nama motif disesuaikan dengan bahasa setempat. Seperti motif bunga manggis yang terdpat pada songket Palembang memiliki kesamaan dengan motif yang menghiasi kain tenun sarung di Jawa, yaitu motif subang berdaun delapan, serta ragam hias tumpal di Jawa yang biasa diterapkan pada kain batik juga memiliki kesamaan bentuk dengan ragam hias pada tenun songket Palembang yaitu dengan nama ragam hias pucuk rebung.

\section{Makna Ragam Hias Motif Nago Besaung}

Kondisi sosial masyarakat Palembang yang mengalami percampuran etnik dan kultur budaya Cina, tidak bisa dipungkiri lagi hampir dari kesemuaan unsur telah mengalami kontaminasi. Hal tersebut dapat dilihat dari makanan, pengetahuan dan kebudayaannya. Begitupun pola pikir mereka (seperti yang telah dijelaskan pada bab dua) yang telah mengalami pengalaman emosi kepercayaan mendalam sekumpulan masyarakat Palembang yang percaya akan hadirnya naga dapat disebut sebagai ekspresi identitas yang melekat dalam masyarakat Palembang. Mengutip pendapat Marcel Danesi, yang menyatakan bahwa mitos adalah narasi yang karakter-karakter utamanya adalah para dewa, para pahlawan, dan makhluk mistis, plotnya berputar disekitar asal muasal benda-benda atau disekitar makna benda-benda, dan settingnya adalah dunia metafisika yang dilawankan dengan dunia nyata (2012: 167).

Jadi secara sadar atau tidak mitos naga yang sampai sekarang masih juga dipercayai merupakan mitos yang telah ada sedari dulu dan berkembang. Maka hal 
tersebut menjadi sesuatu yang dipercayai bersama karena mitos naga tidak hanya merupakan sebuah cerita, tapi juga dipercayai adanya.

Hal yang sedemikianlah menyebabkan naga yang merupakan makhluk mitos dipercayai keberadaannya, dituangkan dalam kebudayaan masyarakat Palembang yang meyakini naga akan membawa pengaruh yang positif dalam kehidupannya. Naga dapat dimaknai sebagai personifikasi dari kebaikan, kebahagiaan, keuntungan, kemakmuran, kesuburan, keperkasaan dan lebih dihubungkan dengan segala hal yang baik (Aby Sofyan, Wawancara 4 Mei 2014). Senada dengan Chandra Wijaya, mengatakan bahwa naga adalah simbol suci yang melambangkan pertumbuhan, harapan, serta kehidupan yang lebih baik (Wawancara 5 April 2014). Semua tampak banyaknya ornamen-ornamen naga yang berada dalam kehidupan sosial mereka, salah satunya pada songket yang diyakini memiliki kekuatan magis sebagai pembawa unsur kebaikan, yang digunakan dalam acara pernikahan masyarakat Palembang.

Masyarakat Palembang memiliki kepercayaan/keyakinan terhadap sifat dari naga itu yang dikonsepsikan sebagai simbol dalam kebudayaan mereka, dalam hal ini lebih memfokuskan pada motif nago besaung di songket Palembang (walaupun banyak ditemukannya ornamen naga pada media lainnya). Naga dipandang sebagai lambang kesuburan, kekuatan naga yang mampu membantu manusia, binatang yang mampu memberikan keselamatan (Rustarmadi, 2012: 74).

Sesungguhnya bentuk simbolis yang diciptakan oleh masyarakat Palembang berawal dari pengalaman yang telah melewati suatu transformasi simbolis. Dengan demikian pengalaman yang dituangkan seniman dalam karya seninya adalah pengalaman yang telah direnungkan menjadi bentuk simbolis. Ekspresi emosi seniman yang telah menjadi karya seni atau simbol merupakan universalisasi pengalaman dan objektifikasi realitas subjektif. Sebenarnya motif disongket (nago besaung) itulah yang kemudian merupakan bentuk simbol dalam penampilan yang lain dari pada yang dihasilkannya. Mengutip Daeng yang menyatakan bahwa simbol berkaitan erat dengan kohesi dan transformasi sosial. Simbol mempersatukan atau menggabungkan suatu segi pengalaman itu maupun pengungkapannya (2000: 82). 
Simbol motif nago besaung merupakan simbol dalam pengertian yang agung, semua dapat dipahami dari songket itu sendiri yang merupakan songket lepus yang artinya memiliki kandungan benang emas yang penuh, sehingga lebih dikenal sebagai songket high class. Selain itu kehadirannya erat kaitan dengan busana pelengkap dalam pernikahan masyarakat Palembang, yang kemudian motif nago besaung lebih dipahami sebagai motif yang memiliki makna bagi pemakainya (pengantin) yang tentunya semua itu telah mengalami kesepakatan (konvensi) dari masyarakat setempat. Semua dapat dipahami bahwa apa yang menjadi tolak ukur (pengetahuan tersebut) sebenarnya merupakan acuan dari pola pikir mereka sendiri. Pemahaman masyarakat Palembang yang mempercayai akan kekuatan sifat naga mereka tuangkan dalam visual songket yang mengharapkan juga akan memiliki kesamaan unsur dari naga itu sendiri.

Mengikuti prinsip 'suatu bentuk akan selalu memiliki makna', maka bentuk naga memiliki makna tersendiri bagi masyarakat Palembang. Naga merupakan simbol perwakilan dari diri mereka. Simbol yang merupakan manifestasi dari keadaan kesadaran dan muncul didalam kebatinan masyarakat Palembang yang dapat memberikan makna pada kehidupan bersosialisasi. Sehingga ketika masyarakat Palembang melihat naga, maka timbul rangsangan memahami bahwa naga merupakan sumber dari kekuatan, nasihat, gambaran dan sejarah leluhurnya. Mengutip Danesi yang mengatakan binatang merupakan sumber-sumber simbolisme (2012: 157)
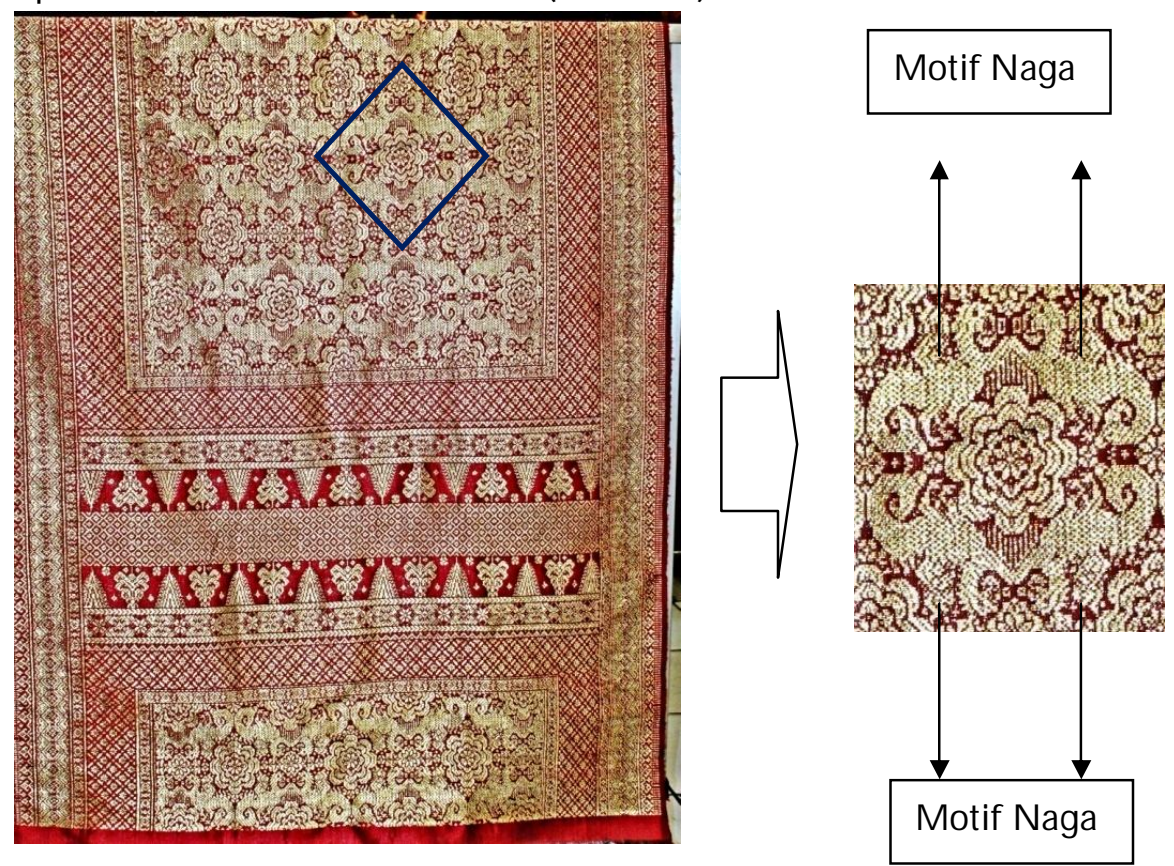

Gambar 1. Songket Palembang Motif Nago Betarung. 
Penggambaran naga yang seolah-olah saling berhadapan, dan membentuk struktur satu kesatuan juga dapat diintepretasikan sebagai wahana dalam menaungi atau untuk menjaga sipemakainya. Seperti yang telah di katakan oleh Diah, naga yang ada pada songket Palembang yang seolah-olah saling berhadapan diyakini masyarakatnya sebagai penjaga untuk pemakainya (Wawancara: 17 Juli 2013), senada dengan Zainal bahwa untuk pengantin menggunakan motif nago besaung, beranjak dari tingginya nilai filosofis naga itu dan penggambaran motif nago dimaknai naga yang sedang dikurung untuk menjaga tali perkawinan sipemakainya (Wawancara, 20 Juli 2013). Bahkan Maya mengatakan bahwa "men nak kawen pakek motif ini kak nago besaung bae, dijagoi nago nah jadi keluargo kakak awet, seneng terus, beduit, pokoknyo jadi keluargo yang seneng" (Wawancara, 6 Juni 2014). Artinya "jika ingin menikah gunakan motif nago besaung, dengan harapan agar pernikahan dijaga oleh naga tersebut dan kesenangan, kejayaan akan menghampiri dalam rumah tangga". Mengutip Danesi yang mengatakan bahwa pakaian saling terhubung dengan upacara dan ritual yang dirancang khusus untuk menyampaikan pesan dan makna (2012: 221).

Sehingga nilai moral yang tertanam pada masyarakat Palembang, semua dapat dirasakan adanya hubungan yang erat kaitannya mengapa masyarakat Palembang memilki kepercayaan tersebut, semua dapat dipahami dari konsep kebudayaan mereka sendiri. Kebudayaan mereka yang meyakini akan kekuatan naga sebagai makhluk yang abadi. Sehingga dalam melangsungkan pernikahan seperti yang dikatakan oleh Diah, masyarakat Palembang menggunakan motif nago betarung sesuai dengan pandangan mereka/kepercayaan terhadap naga yang diyakini merupakan hewan keabadian. Maka dari itu, mereka menyimbolisasikan naga dengan harapan pernikahan mereka kan tetap abadi (Wawancara 17 Juli 2013).

Pemaparan diatas senada dengan yang diungkapkan oleh Purwanti (wawancara, 30 Juli 2013), pemahaman motif naga besaung yang ada pada songket Palembang diartikan sebagai naga yang dikurung, untuk menjaga tali perkawinan masyarakat Palembang. mengutip Peursen yang mengatakan bahwa simbol-simbol di dalam seni dapat memberikan kandungan arti dalam kesuburan, kesucian, kelahiran kembali kewanitaan, cinta, tirani, dan sebagainya. Pengertian ini masuk di dalam karya seni 
sebagai elemen-elemen yang menciptakan serta mengartikulasikan bentuk organisnya, sebagaimana pokok persoalan yang dikandungnya (Peursen, 1993:140).

Pengetahuan di atas dapat dipahami bahwa selain dari tingginya makna filosofis dari naga menurut kepercayaan masyarakat Palembang, yang mengagumi dan mengagungkan makhluk ini juga mereka mengaitkan dengan struktur pola yang melingkupi motif nago besaung tersebut. Yang memang dapat dilihat pada gambar 25 penyususunan motif nago besaung terdiri dari dua pasang yang diletakkan saling berhadapan satu sama lain sehingga perpaduannya kepala bertemu kepala, ekor bertemu ekor yang secara keseluruhan membentuk suatu pola yang seolah-olah berada dalam lingkaran satu kesatuan yang utuh.

Pemahaman masyarakat Palembang yang memaknai bahwa motif nago besaung selain menyimbolkan makna antar elemen-elemennya tetapi juga memaknai secara keseluruhan bahwa makna naga tersebut dalam suatu pola yang utuh. Sehingga tampak pada keseluruhan naga seolah-olah berada dalam satu ruangan atau tampak seperti dikurung yang diinterpretasikan untuk menjaga sipemakainya. Sependapat dengan Langer, yang mengatakan bahwa elemen-elemen dalam suatu simbol seni tidaklah dimungkinkan menetapkan apapun makna yang dikandungnya terpisah dari keseluruhannya (Langer, 1957: 43-135).

Bila motif nago besaung dikonsepsikan sebagai simbol penyelarasan dalam fungsinya (pengantin), maka tidak dapat dipungkiri bahwa pemahaman masyarakat Palembang tentang sifat dari naga yang di tuangkan dalam kain songket merupakan hasil dari pengembangan yang lebih lanjut tentang menyimbolkan perspektif naga pada kain songket. Sehingga pemaknaan bagi pemakainya juga akan merangsang untuk memahami akan makna dari naga itu sendiri.

Pemahaman makna simbolisasi motif nago besaung yang sarat dengan arti simbolis yang kemudian masyarakat Palembang menerapkannya karena mengganggap naga sebagai lambang yang memiliki nilai-nilai magis, spiritual, kebaikan, perlambang kemakmuran, dan kebijaksanaan. Farlin mengatakan bahwa dalam pernikahannya menggunakan motif nago besaung karena percaya bahwa naga akan membawa unsur 
kebaikan dalam rumah tangganya kelak (Wawancara, 20 April 2014). Senada dengan Danesi yang mengatakan bahwa pakaian dapat didefinisikan sebagai tanda yang memperluas makna dasar tubuh dalam konteks budaya, bagian-bagian tertentu yang digunakan memiliki makna khusus (Danesi, 2012: 207-212).

Pengetahuan (kognitif) tersebutlah sehingga masyarakat Palembang yang meyakini bahwa naga merupakan makhluk yang memiliki unsur sakral yang dalam ini kaitannya dimaksudkan sebagai hewan pembawa keberuntungan, dan jika dikonsepsikan pada suatu media maka sifat naga tersebut akan mempengaruhi/memilki kesamaan sifatnya. Sebagai contoh, pemaknaan naga dalam songket memiliki makna pengharapan, yang disimbolisasikan menjadi motif nago besaung. Pada bab dua peneliti menyinggung bahwa dalam suatu tali pernikahan, tentunya orang yang memiliki tali pernikahan tersebut menginginkan atau mengaharapkan sagala sesuatu yang bersifat baik untuk keberlangsungan hidupnya.

Semua menerangkan bahwa simbol yang berakar dari kekuatan naga diyakini dapat menjaga dan melindungi sipemakainya dan semakin kompleks ketika bersinggungan dengan pengantin yang memang harus dilindungi rumah tangganya, karena dalam melangsungkan kehidupan berumah tangga, banyak hal yang harus dimengerti dan dipahami, pernikahan bukan hanya sekedar perhiasan dalam hidup seseorang tetapi lebih jauh lagi bahwa pernikahan merupakan penyatuan dua jiwa insan yang berbeda jenis dan latar belakang, sehingga atas dasar pemahaman tersebut masyarakat Palembang menggunakan motif nago besaung dengan harapan memiliki keselarasan makna antara motif naga yang digunakan dengan sipemakainya.

Perlu dipahami bahwa pernikahan merupakan babak awal dari perjalanan hidup manusia untuk terjun dalam dunia (Yuwono, 2011: 216). Dalam menjalankan pernikahan tidaklah banyak yang berhasil melaluinya, keharmonisan dalam berumah tangga bukanlah merupakan persoalan yang sepele. Semua dikarenakan terdapatnya perbedaan karakter masing-masing yang masih belum bisa memahami atau bahkan menghargai perbedaan. Disinilah sebenarnya konteks dalam sebuah pernikahan yaitu menyatukan perbedaan demi kesamaan dengan tujuan mencapai kesempurnaan. 
Rumah tangga yang dibagun melalui hubungan pernikahan merupakan kerajaan bagi sepasang suami istri dan anak-anaknya kelak. Suami merupakan raja dan istri menjadi permaisurinya. Sebagai kerajaan, rumah tangga perlu menjaga kedaulatan dan kehormatannya, maka dari itu mereka harus mampu menyelesaikan segala sesuatu yang terjadi dalam rumah tangganya.

Konsep tersebutlah yang meyakinkan bahwa masyarakat Palembang memandang sebuah pernikahan merupakan hal yang rentan terhadap badai goncangan (cobaan), mereka memerlukan sesuatu yang dapat mereka andalkan untuk menghadapi cobaan tersebut, disinilah konsep pemaknaan yang terjadi dalam motif nago besaung yang diyakini sebagai pengharapan (doa) untuk menjaga keselarasan/keharmonian dalam rumah tangganya. Mengutip Langer (1957: 140), simbol-simbol didalam seni memberikan kandungan arti kesucian, kelahiran kembali, kewanitaan, tirani, dan cinta.

Paparan di atas merujuk pada pemahaman nilai moral yang tertanam pada masyarakat Palembang sebagaimana memandang bahwa motif nago besaung merupakan motif yang sakral dan sarat makna, mereka meyakini bahwa jika tidak menggunakan motif ini akan terjadi hal yang tidak diinginkan pada pernikahanya.

Sehingga ekspresi yang dapat dirasakan oleh masyarakat Palembang saat ini yang memiliki kepercayaan yang khusus akan hadirnya naga, nilai moral yang tertanam atau terkandung atas kehadiran naga ini menuntun masyarakat Palembang untuk menggunakan motif nago betarung dalam pernikahannya, karena naga diyakini bisa membawa unsur-unsur kebaikan dalam berkehidupannya kelak, sehingga menjadi busana pelengkap dalam pernikahannya hingga saat ini.

\section{D.SIMPULAN}

Songket memiliki jumlah ragam hias yang sangat banyak. Keberagaman ini tidak lepas dari ekspresi yang dituangkan penenunnya yang bersumber dari lingkungan sekitarnya, kepercayaan adat istiadat, tatanan sosial, gaya hidup masyarakatnya yang kesemuaan itu merupakan proses awal dari imajinasi perorangan atau kelompok yang menggambarkan cita-cita atau pengharapan. Sehingga songket dihadirkan tidak hanya 
sebagai benda biasa tanpa makna fakta-fakta budaya melainkan ada makna mental yang terkait dengan persoalan sistem simbol.

Sama halnya pada kain songket motif nago besaung yang dikenal saat ini sebagai pelengkap busana dalam acara pernikahan adat Palembang. Penggunaan motif nago besaung dalam busana pernikahan tentunya dihadirkan bukan hanya sekedar kebetulan saja, motif ini digunakan pasti ada pemahaman-pemahaman bagi masyarakat Palembang atau bisa dikatakan sebagai simbolisasi bagi masyarakatnya.

Hasil analisis menunjukkan bahwa simbolisasi dari motif nago besaung merupakan unsur kepercayaan dari masyarakat Palembang yang di dalamnya mengadung pengertian yang khusus. Kehadirannya erat kaitan dengan pernikahan yang tentunya semua itu telah mengalami kesepakatan (konvensi) dari masyarakat Palembang. Apa yang menjadi tolak ukur sebenarnya merupakan acuan dari pola pikir mereka sendiri. Pemahaman masyarakat Palembang yang mempercayai akan kekuatan sifat naga mereka tuangkan dalam visual songket yang mengharapkan juga akan memiliki sifat dari naga itu sendiri.

Pemahaman makna simbolisasi motif nago besaung yang digunakan sebagai busana pelengkap dalam pernikahan masyarakat Palembang sebagaimana pemaparan diatas tidaklah heran jika naga yang sarat dengan arti simbolis yang kemudian masyarakat Palembang menerapkannya karena mengganggap naga sebagai lambang yang memiliki nilai-nilai magis, spiritual, kebaikan, perlambang kemakmuran, kebaikan dan kebijaksanaan.

Masyarakat Palembang menggunakan motif nago besaung dalam tradisi mereka yaitu pernikahan. Dimana pemahaman dalam menjalin hubungan dalam ikatan tali pernikahan tentunya nilai dari berkehidupan yang sebenarnya harus ditanamkan. Karena menyatukan perbedaan untuk kesamaan menuju kesempurnaan bukanlah merupakan hal yang mudah. Keyakinan masyarakat Palembang akan hal inilah yang mengakibatkan terjalinnya hubungan antara pernikahan dan simbol motif nago besaung. Mereka mempunyai pengharapan agar dalam rumah tangganya akan berjalan sesuai dengan apa 
yang diharapkan, selaras dengan makna simbolik yang terdapat pada motif nago besaung yang mereka gunakan.

Tertangkap bahwa masyarakat Palembang memiliki sistem simbol yang mereka percayai sebagai sesuatu yang dapat mengkukuhkan dirinya sebagai masyarakat komunal. Simbol kerakyatannya merupakan bagian terpenting dari apa yang mereka pelihara sebagai bentuk warisan dari generasi kegenarasi. Cara-cara tindakan simbolik yang mereka gunakan masih berdasarkan norma dan aturan atau tatacara lama tentang bagaimana memperlakukan adat-istiadat yang hidup dan berkembang dilingkungannya.

\section{DAFTAR PUSTAKA}

Basuki Teguh Yuwono, keris naga. Indonesia: Badan Pengembangan Sumber Daya Kementerian Pariwisata dan Ekonomi Kreatif, 2011.

Daeng, Hans, J. Manusia Kebudayaan dan Lingkungan. Yogyakarta: Pustaka Pelajar, 2000.

Guntur. Ornamen (sebuah Pengantar). Surakarta: P2AI bekerja sama dengan STSI Press, 2004.

Langer, Susanne Knauth. Problem of Art: Ten philosophical Lectures. Edition 6. New York: Charles Scribner Sons, 1957.

Marcel Danesi. Pesan, Tanda, dan Makna. Yogyakarta: Jalasutra, 2012.

Nusyirwan. Ragam Hias Songket Minangkabau. Padang: Proyek Pengembangan Permuseuman Sum-Bar, 1982.

Peursen, C.A.Van. Strategi Kebudayaan, cetakan keempat Kanisius: Yogyakarta, 1993.

Rustarmadi. Makna Simbolis Ragam Hias Pendapa Teras Candi Panataran. Journal: Seni Rupa Universitas Negeri Surabaya, 2012.

Soegeng Toekio. Mengenal Ragam Hias Indonesia. Surakarta: Proyek pengembangan IKI Sub Proyek Aski Surakarta, 1983/1984. 
Suwati Kartiwa. Kain Songket Indonesia. Djambatan, 1989.

Ragam Kain Tradisional Indonesia (Tenun Ikat). Jakarta: Gramedia Pustaka Utama, 2007.

Syamsir Alam, dkk. Kain Songket Palembang. Palembang: Departemen Pendidikan dan Kebudayaan Bagian Proyek Pembinaan Permuseuman Sumatera Selatan, $1995 / 1996$ 